\title{
NOTA DE APOIO AO POVO KAINGANG
}

Nós, enquanto parte do corpo discente do Programa de PósGraduação em Antropologia Social da Universidade Federal do Rio Grande do Sul (UFRGS), juntamente com professores e pesquisadores que participaram e/ou apoiaram a elaboração deste documento, vinculados ao Laboratório de Arqueologia e Etnologia (LAE-UFRGS), ao Núcleo de Antropologia das Sociedades Indígenas e Tradicionais (NITUFRGS), ao Núcleo de Antropologia e Cidadania (NACl-UFRGS), e ao Núcleo de Etnologia Ameríndia (NETA) da Universidade Federal de Pelotas, viemos por meio desta nota manifestar nosso repúdio à prisão de cinco indígenas kaingang na região noroeste do estado do Rio Grande do Sul, dentre eles o cacique da aldeia Kandóia-Votoro (município de Faxinalzinho), Deoclides de Paula, ocorridas no dia 09 de maio.

Não podemos negligenciar o fato de que, em 2013, no Brasil, aconteceram 15 mortes e 10 tentativas de assassinatos de indígenas por disputas de terra dos quais a sociedade brasileira praticamente não volta sua atenção, principalmente devido à forma sensacionalista e revanchista com que os fatos são tratados. Neste contexto em particular, prestamos nossos sentimentos aos familiares e amigos de Alcemar Batista de Souza e Anderson de Souza encontrados mortos, no dia 28 de abril, próximos ao ponto em que os moradores da aldeia Kandóia se manifestavam. Sabemos que pouco pode ser feito para amenizar sua perda. Para tanto, atentamos para o fato de que as condições tendem a se agravar, e que a análise do conflito deve ser pensada numa perspectiva mais ampla, não restrita à localidade, pois o mesmo amplia-se em vários sentidos, que extrapolam a nossa compreensão imediata, tal como, por exemplo, sua relação com a morte por espancamento de um Kaingang próximo à Estação Rodoviária de 
Três de Maio, na mesma região noroeste do estado, também no domingo dia 09/05/2014.

Diante dos fatos ocorridos e manifestando em público o conteúdo de nossas pesquisas, reafirmamos a importância de contextualizar a reivindicação da Aldeia Kandóia e, assim, informar que esta aldeia está há mais de 10 anos em procedimento administrativo de regularização, tendo este processo passado pelas primeiras etapas exigidas, conforme a Constituição Federal/1988, o Decreto $1.775 / 1996$ e a Portaria 14, que dizem respeito à forma jurídica para tramitação da reivindicação no órgão competente, FUNAI. O processo encontra-se atualmente à espera de assinatura da Portaria Declaratória pelo Ministro da Justiça, José Eduardo Cardozo, o que implica no dever público por parte da autoridade competente em aplicar o Estatuto do Índio de 1973, legislação em vigor e que é complementar, na compreensão de nossa jurisprudência, para o justo cumprimento do dispositivo constitucional e, em última instância, o respeito à Convenção 169 da OIT, da qual o Brasil é signatário.

Desse modo, considerando que foram implementados os exaustivos procedimentos que conduziram esse pleito territorial até 0 estágio atual, observados os princípios constitucionais e realizados os instrumentos técnicos exigidos para a aplicação do conhecimento antropológico e no sentido de garantir os direitos relacionados aos povos indígenas, viemos reiterar a legitimidade e legalidade do processo que traduz a tradicionalidade da ocupação Kaingang na Aldeia Kandóia, isto é, caracterizando-a como por eles habitada em caráter permanente, utilizada para suas atividades produtivas, imprescindível à preservação dos recursos ambientais necessários a seu bem-estar e necessária a sua reprodução física e cultural, segundo seus usos, costumes e tradições.

Sabemos que o histórico das demarcações de terras indígenas no Brasil demonstra que a prioridade tem sido as áreas localizadas na Amazônia Legal, deixando em segundo plano as áreas reivindicadas nas regiões Sul, Sudeste e Centro-Oeste. Enquanto não houver uma real mobilização do Estado para a demarcação dessas áreas, os conflitos tendem a se acirrar cada vez mais. A omissão do Estado Brasileiro, com especial menção aos órgãos competentes, é responsável pelo acirramento dos conflitos na região. Alertamos que este quadro se 
agrava com o incentivo, por parte de parlamentares do estado, ao armamento e contratação de polícias privadas no combate a processos de demarcação amparados pela legislação brasileira.

Por fim, a ética antropológica e a garantia dos direitos indígenas orientam as ações da nossa comunidade científica para, neste momento, situar a ação da Polícia Federal como imprópria e arbitrária e exigir a imediata soltura dos cinco kaingang presos no dia 09 de Maio de 2014. Também exigimos a homologação imediata da área reivindicada pelos Kaingang da Aldeia Kandóia, bem como a agilidade na tramitação de outros processos de regularização de terras indígenas atualmente paralisados na FUNAI. A demarcação das Terras Indígenas, conforme os princípios constitucionais antes expressos, é o que torna possível a continuidade da vida indígena conforme suas formas próprias e singulares de concepção de mundo e a sua integridade enquanto grupo.

Porto Alegre, 15 de maio de 2014. 